\title{
Mitoxantrone-Induced Suicidal Erythrocyte Death
}

\author{
Markus Arnold Rosi Bissinger Florian Lang \\ Department of Physiology, University of Tübingen, Tübingen, Germany
}

\author{
Key Words \\ Phosphatidylserine $\bullet$ Mitoxantrone $\bullet$ Calcium $\bullet$ Ceramide $\bullet$ Cell volume $\bullet$ Eryptosis
}

\begin{abstract}
Background/Aims: Mitoxantrone, a cytotoxic drug used for the treatment of malignancy and multiple sclerosis, is at least in part effective by triggering apoptosis. Similar to apoptosis of nucleated cells, erythrocytes may enter eryptosis, a type of suicidal cell death. Hallmarks of eryptosis are cell shrinkage and cell membrane scrambling with phosphatidylserine translocation to the erythrocyte surface. Signalling involved in eryptosis include $\mathrm{Ca}^{2+}$-entry, ceramide formation and oxidative stress. Methods: Cell volume was estimated from forward scatter, phosphatidylserine-exposure from annexin $\mathrm{V}$ binding, formation of reactive oxidant species (ROS) from 2',7'-dichlorodihydrofluorescein-diacetate fluorescence, and ceramide abundance from binding of fluorescent antibodies in flow cytometry. Results: A 48 hours exposure to mitoxantrone was followed by significant decrease of forward scatter $(\geq 5 \mu \mathrm{g} / \mathrm{ml}$ mitoxantrone) and increase of annexin-V-binding ( $\geq 10 \mu \mathrm{g} / \mathrm{ml}$ mitoxantrone), effects paralleled by significant increases of ROS formation ( $25 \mu \mathrm{g} / \mathrm{ml}$ mitoxantrone) and ceramide abundance $(25 \mu \mathrm{g} / \mathrm{ml}$ mitoxantrone). The effect of mitoxantrone was not significantly modified by nominal absence of extracellular $\mathrm{Ca}^{2+}$ but significantly blunted by the antioxidant $\mathrm{N}$-acetylcysteine (1 $\mathrm{mM})$. Conclusions: Mitoxantrone triggers cell membrane scrambling, an effect not requiring entry of extracellular $\mathrm{Ca}^{2+}$ but at least partially due to formation of ROS and ceramide.
\end{abstract}

Copyright $@ 2014$ S. Karger AG, Basel

\section{Introduction}

Mitoxantrone, a synthetic antineoplastic cytotoxic drug [1], is used for the treatment of both, aggressive multiple sclerosis [1,2] and malignancy [3-10]. The antineoplastic effects result from triggering of tumor cell apoptosis [11-17], the efficacy of mitoxantrone in multiple sclerosis has been attributed to apoptosis of lymphocytes and dendritic cells [18]. 
Furthermore, mitoxantrone may induce cell senescence [19]. Side effects of mitoxantrone include leukemia [20], cardiotoxicity [21], anemia [21] and thrombosis [22-27].

In analogy to apoptosis of nucleated cells, erythrocytes may enter eryptosis, the suicidal erythrocyte death. Hallmarks of eryptosis are cell shrinkage and cell membrane scrambling with phosphatidylserine exposure to the erythrocyte surface [28]. Triggers of eryptosis include entry of $\mathrm{Ca}^{2+}$ with subsequent increase of cytosolic $\mathrm{Ca}^{2+}$ concentration $\left(\left[\mathrm{Ca}^{2+}\right]_{\mathrm{i}}\right)[29]$, oxidative stress [28], ceramide formation [28], caspase activation [30-34], knockout of AMP activated kinase AMPK [35], or of cGMP-dependent protein kinase [36], inhibition of p21 activated kinase [37] or sorafenib [38] and sunitinib [39] sensitive kinases and/or activation of casein kinase $1 \alpha[40,41]$, Janus-activated kinase JAK3 [42], protein kinase C [43] or p38 kinase [44].

The present study tested, whether mitoxantrone stimulates eryptosis, and explored the impact of putative underlying mechanisms, such as $\mathrm{Ca}^{2+}$ entry, oxidative stress, p38 kinase and ceramide formation.

\section{Materials and Methods}

Erythrocytes, solutions and chemicals

Fresh Lithium-Heparin-anticoagulated blood samples were kindly provided by the blood bank of the University of Tübingen. The study is approved by the Ethics Committee of the University of Tübingen $(184 / 2003 V)$. The blood was centrifuged at $120 \mathrm{rcf}$ for 20 minutes at $23^{\circ} \mathrm{C}$ and the platelets and leukocytescontaining supernatant was disposed. Erythrocytes were washed in Ringer solution containing (in mM) 125 $\mathrm{NaCl}, 5 \mathrm{KCl}, 1 \mathrm{MgSO}_{4}, 32 \mathrm{~N}$-2-hydroxyethylpiperazine-N-2-ethanesulfonic acid (HEPES), 5 glucose, $1 \mathrm{CaCl}_{2} ; \mathrm{pH}$ 7.4. For the experiments, erythrocytes were incubated in vitro at a hematocrit of $0.4 \%$ at $37^{\circ} \mathrm{C}$ for 48 hours. Where indicated, erythrocytes were exposed to mitoxantrone (Sigma-Aldrich, Hamburg, Germany) at the indicated concentrations. In $\mathrm{Ca}^{2+}$-free Ringer solution, $1 \mathrm{mM} \mathrm{CaCl}_{2}$ was substituted by $1 \mathrm{mM}$ glycol-bis(2aminoethylether)-N,N,N',N'-tetraacetic acid (EGTA). Where indicated, the antioxidant $\mathrm{N}$-acetylcysteine (1 mM) or the p38 kinase blocker SB $203580(2 \mu \mathrm{M})$ was added.

\section{FACS analysis of annexin-V-binding and forward scatter}

After incubation under the respective experimental condition, $50 \mu \mathrm{l}$ cell suspension was washed in Ringer solution containing $5 \mathrm{mM} \mathrm{CaCl}_{2}$ to provide $\mathrm{Ca}^{2+}$ for $\mathrm{Ca}^{2+}$-dependent Annexin-V-FITC-binding. Cells were then stained with Annexin-V- fluorescein isothiocyanate (FITC) (1:200 dilution; ImmunoTools, Friesoythe, Germany) in this solution at $37^{\circ} \mathrm{C}$ for 20 min under protection from light. In the following, the forward scatter (FSC) of the cells was determined, and annexin-V-FITC fluorescence intensity was measured with an excitation wavelength of $488 \mathrm{~nm}$ and an emission wavelength of $530 \mathrm{~nm}$ on a FACS-calibur from Becton Dickinson (Heidelberg, Germany).

Measurement of intracellular $\mathrm{Ca}^{2+}$

After incubation, erythrocytes were washed in Ringer solution and then loaded with Fluo-3/AM (Biotium, Hayward, USA) in Ringer solution containing $5 \mathrm{mM} \mathrm{CaCl}_{2}$ and $5 \mu \mathrm{M}$ Fluo-3/AM. The cells were incubated at $37^{\circ} \mathrm{C}$ for $30 \mathrm{~min}$ and washed twice in Ringer solution containing $5 \mathrm{mM} \mathrm{CaCl}{ }_{2}$. The Fluo-3/ AM-loaded erythrocytes were resuspended in $200 \mu \mathrm{l}$ Ringer. Then, $\mathrm{Ca}^{2+}$-dependent fluorescence intensity was measured with an excitation wavelength of $488 \mathrm{~nm}$ and an emission wavelength of $530 \mathrm{~nm}$ on a FACS Calibur.

Determination of oxidative stress

Reactive oxygen species (ROS) production was determined utilizing $2^{\prime}, 7^{\prime}$-dichlorodihydrofluorescein diacetate (DCFDA) [45]. Briefly, the cells were suspended in Ringer solution and the fluorescence was analysed with flow cytometry (FACS-calibur). DCFDA fluorescence intensity was measured with an excitation wavelength of $488 \mathrm{~nm}$ and an emission wavelength of $530 \mathrm{~nm}$. 


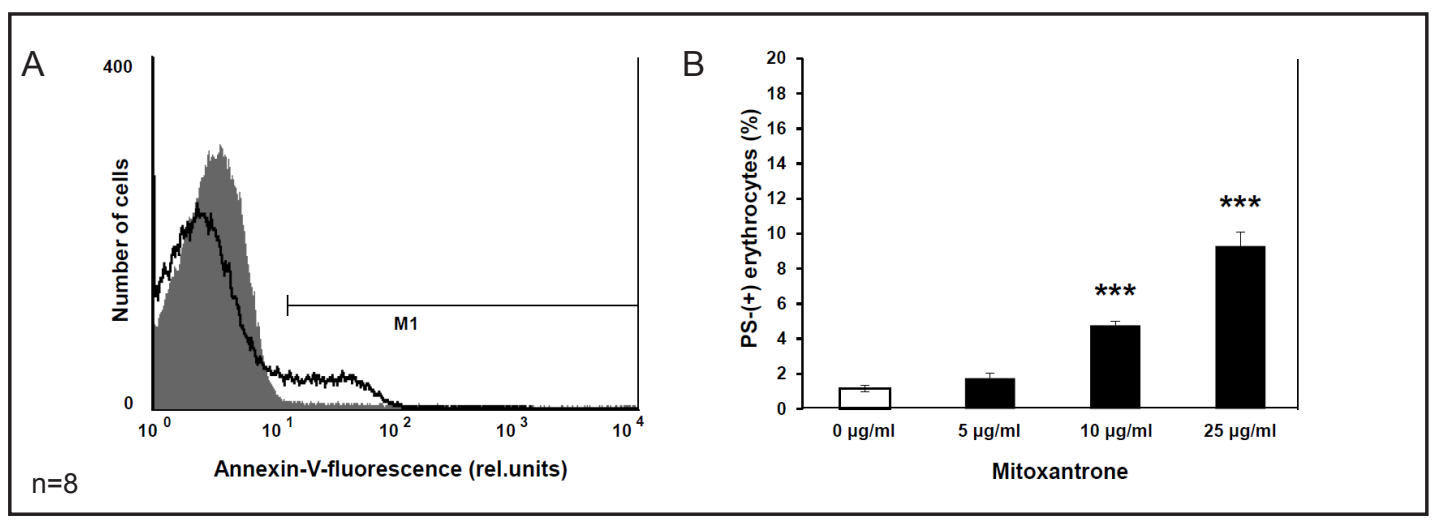

Fig. 1. Effect of mitoxantrone on phosphatidylserine exposure. A. Original histogram of annexin-V-binding of erythrocytes (M1) following exposure for 48 hours to Ringer solution without (grey shadow) and with (black line) presence of $25 \mu \mathrm{g} / \mathrm{ml}$ mitoxantrone. B. Arithmetic means \pm SEM $(\mathrm{n}=8)$ of annexin-V-binding (i.e. phosphatidylserine-positive, PS-(+)) erythrocytes in \% following incubation for 48 hours to Ringer solution without $(1 \mu \mathrm{g} / \mathrm{ml}$ DMSO alone, white bar) or with (black bars) presence of mitoxantrone $(5-25 \mu \mathrm{g} / \mathrm{ml}$ in $1 \mu \mathrm{g} / \mathrm{ml}$ DMSO). ${ }^{* * *}(\mathrm{p}<0.001)$ indicates significant difference from the absence of mitoxantrone [presence of DMSO alone] (ANOVA).

\section{Determination of ceramide formation}

For the determination of ceramide, a monoclonal antibody-based assay was used. After incubation, cells were stained for 1 hour at $37^{\circ} \mathrm{C}$ with $0.1 \mu \mathrm{g} / \mathrm{ml}$ anti ceramide antibody (clone MID 15B4, Alexis, Grünberg, Germany) diluted in PBS containing $0.1 \%$ bovine serum albumin (BSA). The samples were washed twice with PBS-BSA. Subsequently, the cells were stained for 30 minutes with polyclonal FITC-conjugated goat anti-mouse IgG and IgM specific antibody (Pharmingen, Hamburg, Germany) diluted 1:50 in PBS-BSA. Unbound secondary antibody was removed by repeated washing with PBS-BSA. The samples were then analyzed by flow cytometric analysis with an excitation wavelength of $488 \mathrm{~nm}$ and an emission wavelength of $530 \mathrm{~nm}$.

\section{Measurement of hemolysis}

For the determination of hemolysis, the samples were centrifuged (3 min at $1600 \mathrm{rpm}$, room temperature) after incubation under the above mentioned experimental condition, the supernatants were harvested. As a measure of hemolysis, the hemoglobin $(\mathrm{Hb})$ concentration of the supernatant was determined photometrically at $405 \mathrm{~nm}$. The absorption of the supernatant of erythrocytes lysed in distilled water was defined as $100 \%$ hemolysis.

Statistics

Data are expressed as arithmetic means \pm SEM. As indicated in the figure legends, statistical analysis was made using one-way ANOVA with Tukey's test as post-test and two-tailed $t$-test as appropriate. The number of different erythrocyte specimens studied is given as $\mathrm{n}$. Since different erythrocyte specimens used in distinct experiments are differently susceptible to triggers of eryptosis, the same erythrocyte specimens have been used for control and experimental conditions.

\section{Results}

The present study explored, whether mitoxantrone triggers eryptosis, the suicidal erythrocyte death. The hallmarks of eryptosis include cell membrane scrambling with phosphatidylserine translocation to the cell surface. Annexin-V-binding was quantified by flow cytometry in order to identify phosphatidylserine exposing erythrocytes. As illustrated in Fig. 1, a 48 hours treatment with mitoxantrone was followed by an increase of the percentage annexin-V-binding erythrocytes, an effect reaching statistical significance at 10 $\mu \mathrm{g} / \mathrm{ml}$ mitoxantrone concentration. 


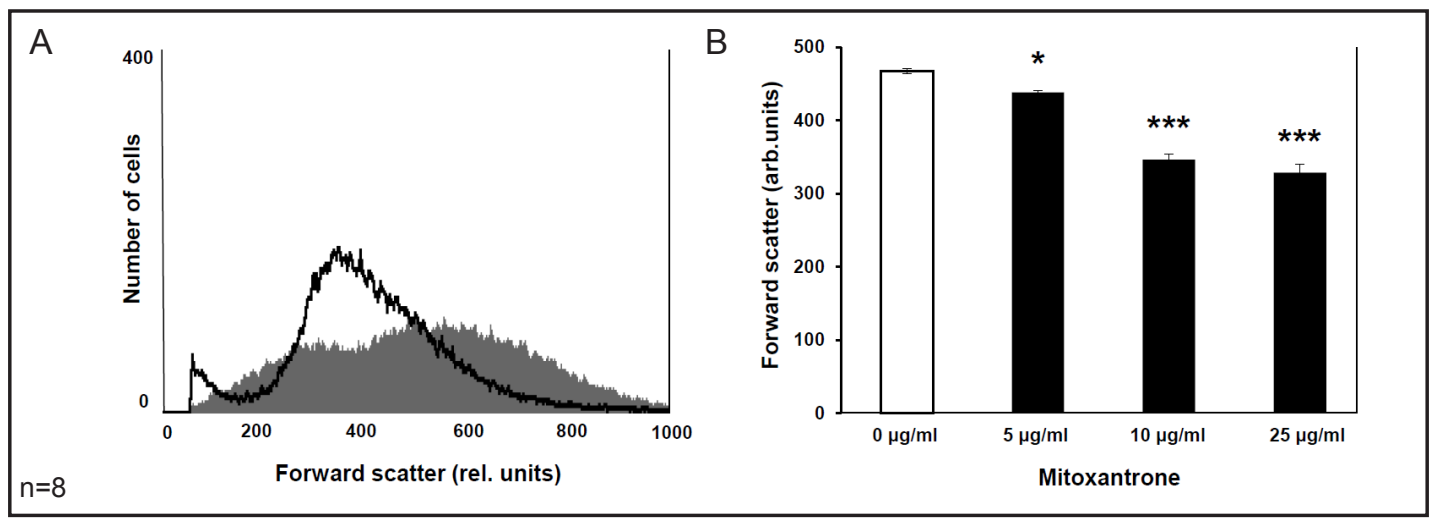

Fig. 2. Effect of mitoxantrone on erythrocyte forward scatter. A. Original histogram of forward scatter of erythrocytes following exposure for 48 hours to Ringer solution without (grey shadow) and with (black line) presence of $25 \mu \mathrm{g} / \mathrm{ml}$ mitoxantrone. B. Arithmetic means \pm SEM $(\mathrm{n}=8)$ of the normalized erythrocyte forward scatter (FSC) following incubation for 48 hours to Ringer solution without (1 $\mu \mathrm{g} / \mathrm{ml}$ DMSO alone, white bar) or with (black bars) mitoxantrone $(5-25 \mu \mathrm{g} / \mathrm{ml}$ in $1 \mu \mathrm{g} / \mathrm{ml} \mathrm{DMSO}) .{ }^{*}(\mathrm{p}<0.05),{ }^{* * *}(\mathrm{p}<0.001)$ indicate significant differences from the absence of mitoxantrone [presence of DMSO alone] (ANOVA).

Fig. 3. Effect of mitoxantrone in the presence and absence of extracellular $\mathrm{Ca}^{2+}$. A,B Arithmetic means \pm SEM ( $n=4-5)$ of the percentage of annexin-V-binding erythrocytes after a 48 hours treatment with Ringer solution without (white bars) or with (black bars) 25 $\mu \mathrm{g} / \mathrm{ml}$ mitoxantrone in the presence (left bars, Plus Calcium) and absence (right bars, Minus Calcium) of calcium without (A) and with (B) EGTA added. $* * *(p<0.001)$ indicates significant difference from the respective values in the absence of mitoxantrone (ANOVA).

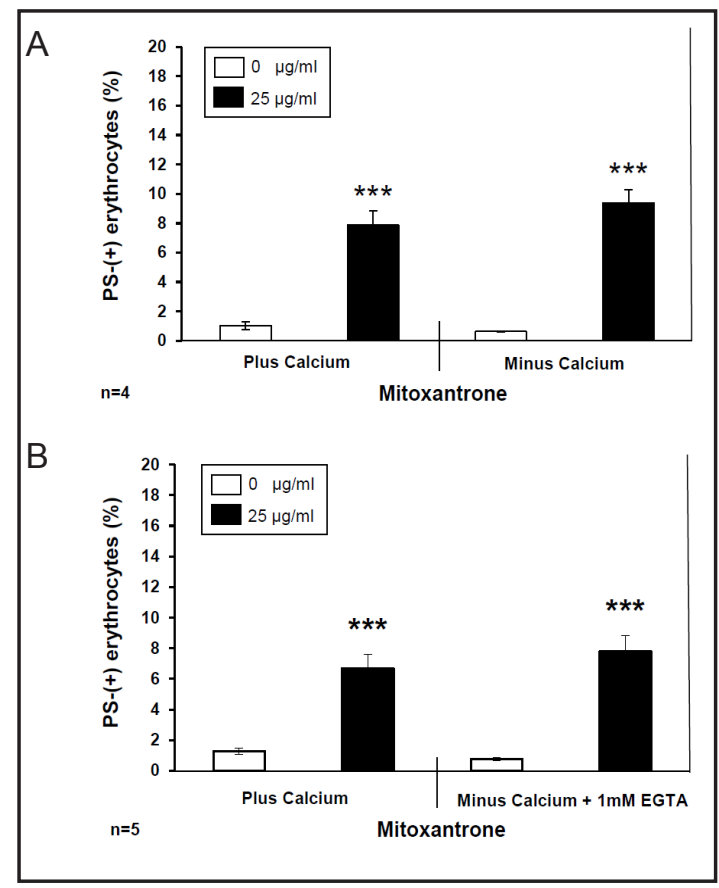

Erythrocyte death could involve hemolysis, a cell death distinct from eryptosis. In order to determine, whether mitoxantrone triggers hemolysis, the percentage of hemolysed erythrocytes was quantified from hemoglobin concentration in the supernatant. As a result, following a 48 hours incubation with $0,5,10$ and $25 \mu \mathrm{g} / \mathrm{ml}$ mitoxantrone, respectively, the hemoglobin concentration in the supernatant approached $1.3 \pm 0.6 \%, 1.5 \pm 0.2 \%, 5.9 \pm$ $2.5 \%$, and $8.5 \pm 0.8 \%\left[{ }^{* *}\right]$ of hemoglobin concentration following complete hemolysis (n $=5$ ). The difference between presence and absence of mitoxantrone reached statistical significance $(\mathrm{p}<0.01)$ at $25 \mu \mathrm{g} / \mathrm{ml}$ mitoxantrone concentration (ANOVA).

Eryptosis is further characterized by cell shrinkage. Accordingly, cell volume was estimated from forward scatter in flow cytometry. As illustrated in Fig. 2, a 48 hours treatment with mitoxantrone decreased forward scatter, an effect reaching statistical significance at 5 $\mu \mathrm{g} / \mathrm{ml}$ mitoxantrone concentration. 


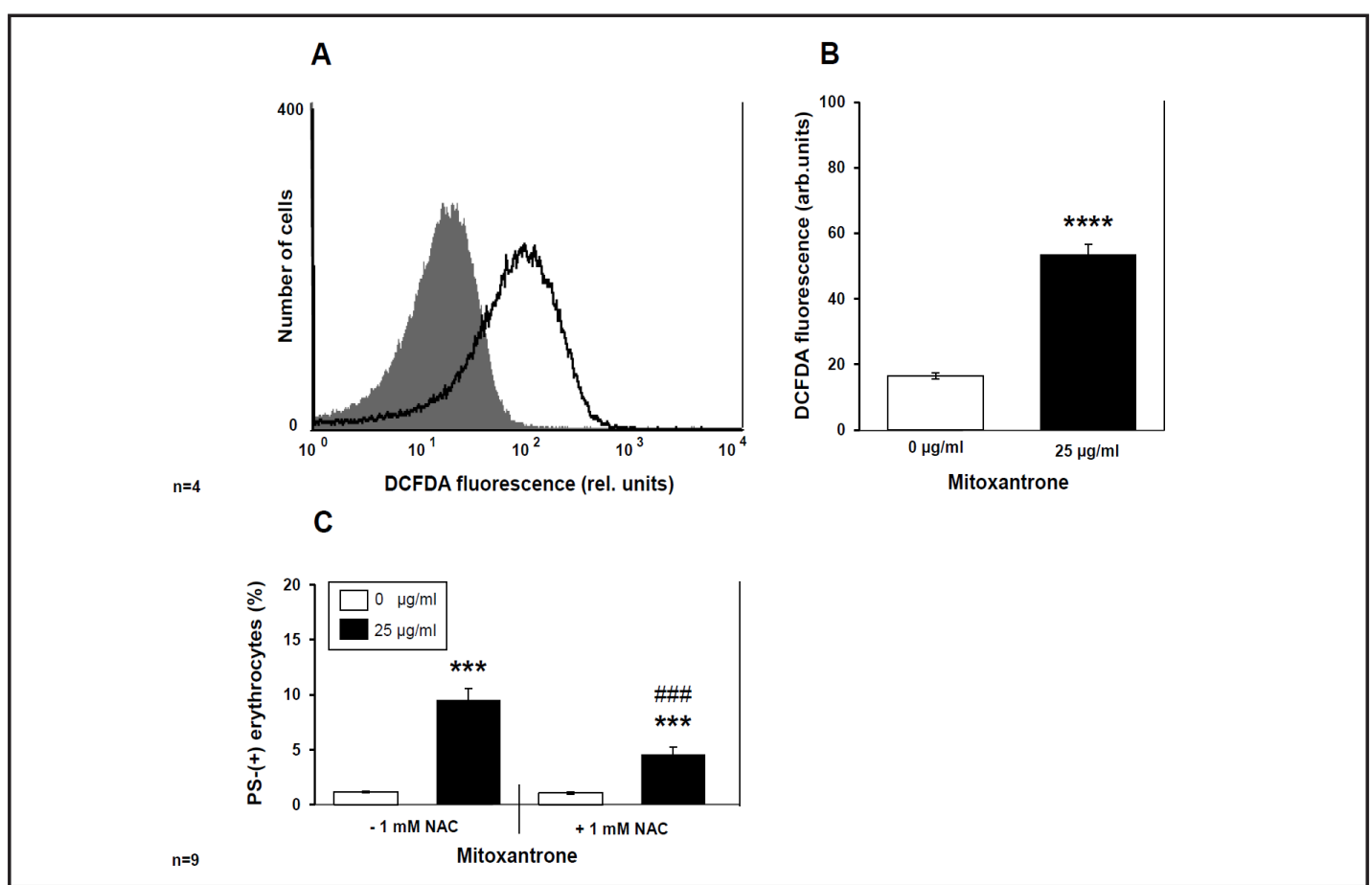

Fig. 4. Effect of mitoxantrone on reactive oxygen species. A. Original histogram of DCFDA-fluorescence in erythrocytes following exposure for 48 hours to Ringer solution without (grey shadow) and with (black line) presence of $25 \mu \mathrm{g} / \mathrm{ml}$ mitoxantrone. B. Arithmetic means \pm SEM $(\mathrm{n}=4)$ of erythrocyte DCFDA fluorescence following incubation for 48 hours to Ringer solution without (white bar) or with (black bar) presence of mitoxantrone $(25 \mu \mathrm{g} / \mathrm{ml}) . * * * *(\mathrm{p}<0.0001)$ indicates significant difference from the absence of mitoxantrone (two-tailed t-test). C. Arithmetic means \pm SEM $(n=9)$ of the percentage of annexin-V-binding erythrocytes after a 48 hours treatment with Ringer solution without (white bars) or with (black bars) 25 $\mu \mathrm{g} / \mathrm{ml}$ mitoxantrone in the absence (left bars, -NAC) and presence (right bars, +NAC) of the antioxidant $\mathrm{N}$-acetylcysteine $(1 \mathrm{mM}) .{ }^{* * *}(\mathrm{p}<0.001)$; indicates significant difference from the respective values in the absence of mitoxantrone (ANOVA), \#\#\# ( $<<0.001)$ indicates significant difference from the respective values in the absence of $\mathrm{N}$-acetylcysteine (ANOVA).

Cell membrane scrambling and cell shrinkage following mitoxantrone treatment could have been due to increase of cytosolic $\mathrm{Ca}^{2+}$ activity $\left(\left[\mathrm{Ca}^{2+}\right]_{\mathrm{i}}\right)$ resulting from entry of extracellular $\mathrm{Ca}^{2+}$. Attempts to quantify $\left[\mathrm{Ca}^{2+}\right]_{\mathrm{i}}$ in erythrocytes utilizing Fluo3 fluorescence failed, as the cells apparently lost the dye following mitoxantrone treatment (data not shown). Possibly, mitoxantrone compromizes cell membrane integrity leading to hemolysis on the one hand and loss of Fluo3 on the other. In order to test, whether the effect of mitoxantrone on cell membrane scrambling required the entry of extracellular $\mathrm{Ca}^{2+}$, erythrocytes were exposed for 48 hours to $25 \mu \mathrm{g} / \mathrm{ml}$ mitoxantrone in the presence or nominal absence of extracellular $\mathrm{Ca}^{2+}$. As shown in Fig. 3, the effect of mitoxantrone on annexin-V-binding was not significantly different between the nominal absence and the presence of $\mathrm{Ca}^{2+}$. Mitoxantrone significantly increased the percentage of annexin-V-binding erythrocytes in both, the absence and presence of extracellular $\mathrm{Ca}^{2+}$. This result indicates that the effect of mitoxantrone on cell membrane scrambling did not require $\mathrm{Ca}^{2+}$ entry.

Further experiments addressed alternative mechanisms possibly involved in the effect of mitoxantrone on eryptosis. The ROS-formation was determined utilizing DCFDA. As illustrated in Fig. 4A,B, a 48 hours exposure to $25 \mu \mathrm{g} / \mathrm{ml}$ mitoxantrone markedly and significantly increased the DCFDA fluorescence, a finding pointing to induction of oxidative stress. In order to test, whether ROS was required for the full effect of mitoxantrone on cell membrane scrambling, erythrocytes were exposed for 48 hours to $25 \mu \mathrm{g} / \mathrm{ml}$ mitoxantrone in the absence and presence of the antioxidant $\mathrm{N}$-acetylcysteine $(1 \mathrm{mM})$. As illustrated in Fig. 


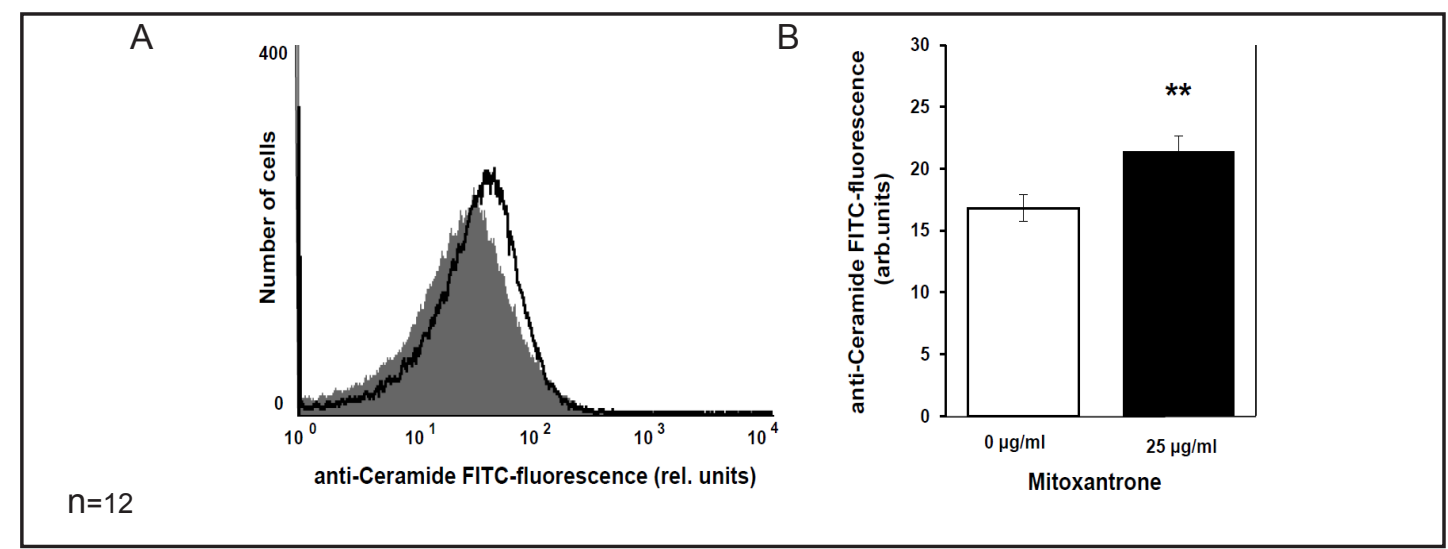

Fig. 5. Effect of mitoxantrone on ceramide abundance. A. Original histogram of anti-ceramide FITC fluorescence in erythrocytes after exposure for 48 hours to Ringer solution without (grey shadow) and with (black line) presence of $25 \mu \mathrm{g} / \mathrm{ml}$ mitoxantrone. B. Arithmetic means \pm SEM $(\mathrm{n}=12)$ of ceramide abundance at the erythrocyte surface following incubation for 48 hours to Ringer solution without (white bar) or with (black bar) presence of mitoxantrone $(25 \mu \mathrm{g} / \mathrm{ml}) .{ }^{* *}(\mathrm{p}<0.01)$ indicates significant difference from the absence of mitoxantrone (two-tailed t-test)

4C, the effect of mitoxantrone on annexin-V-binding was significantly blunted in the presence of $\mathrm{N}$-acetylcysteine. This result indicates that the effect of mitoxantrone on cell membrane scrambling was at least partially due to oxidative stress.

In order to test, whether the effect of mitoxantrone required activation of p38 kinase, experiments were performed in the absence and presence of the p38 kinase inhibitor SB203580 $(2 \mu \mathrm{M})$. As a result, a 48 hours exposure to $25 \mu \mathrm{g} / \mathrm{ml}$ mitoxantrone increased the percentage of annexin-V-binding erythrocytes significantly from $1.7 \pm 0.3 \%$ to $11.3 \pm$ $0.8 \%$ in the absence of SB203580 and significantly from $1.9 \pm 0.4 \%$ to $11.2 \pm 0.8 \%$ in the presence of SB203580. The increase was similar in the absence and presence of SB203580 indicating that activation of p38 kinase was not required for the stimulation of eryptosis by mitoxantrone.

As cell membrane scrambling could further be triggered by ceramide, additional experiments tested, whether mitoxantrone increases the ceramide abundance at the erythrocyte surface. The abundance of ceramide at the erythrocyte surface was quantified utilizing anti-ceramide antibodies. As illustrated in Fig. 5, a 48 hours exposure to $25 \mu \mathrm{g} /$ $\mathrm{ml}$ mitoxantrone was followed by a significant increase of ceramide abundance at the erythrocyte surface.

\section{Discussion}

The present study discloses a novel effect of mitoxantrone, i.e. stimulation of eryptosis, the suicidal erythrocyte death characterized by cell shrinkage and breakdown of phosphatidylserine asymmetry of the erythrocyte cell membrane. The mitoxantrone concentrations required for the stimulation of eryptosis are within the range of mitoxantrone concentrations required for the antineoplastic activity of the substance [46]. At least in theory, the erythrocytes could be sensitized to the effect of mitoxantrone by parallel exposure to further eryptosis triggering xenobiotics [28, 39, 47-73]. Moreover, the sensitivity to mitoxantrone may be increased in patients suffering from disorders with enhanced eryptosis [28], such as diabetes [34, 74, 75], dehydration [76], renal insufficiency [77, 78], hemolytic uremic syndrome [79], sepsis [80], malaria [81], sickle cell disease [81], Wilson's disease [82], iron deficiency [83], malignancy [84], phosphate depletion [85], and metabolic syndrome [65].

The effect of mitoxantrone did not require $\mathrm{Ca}^{2+}$ entry. Whether or not mitoxantrone modifies cytosolic $\mathrm{Ca}^{2+}$ activity $\left(\left[\mathrm{Ca}^{2+}\right]_{\mathrm{i}}\right)$, cannot be answered with certainty. The exposure to 
mitoxantrone was followed by a decline of Fluo3 fluorecence, which may result from decrease of $\left[\mathrm{Ca}^{2+}\right]_{i}$ or from loss of dye. Whatever effect mitoxantrone exerts on $\left[\mathrm{Ca}^{2+}\right]_{i}$, the effect appears not to be relevant for the triggering of eryptosis. We thus explored further putative mechanisms. As evident from DCFDA fluorescence, mitoxantrone induces oxidative stress, a well known trigger of eryptosis [28]. Mitoxantrone has previously been shown to similarly induce oxidative stress of nucleated cells [8,86-88]. On the other hand, mitoxantrone may strengthen the antioxidative defence $[89,90]$. The latter effect presumably requires expression of the respective proteins, an effect not possible in erythrocytes. In erythrocytes oxidative stress activates $\mathrm{Ca}^{2+}$ permeable cation channels with subsequent $\mathrm{Ca}^{2+}$ entry [91], an effect apparently not critically important for the stimulation of cell membrane scrambling by mitoxantrone. Oxidative stress further activates erythrocyte $\mathrm{Cl}^{-}$channels and aspartyl and cysteinyl proteases [91]. Additional experimentation will be required to fully elucidate the link between mitoxantrone induced oxidative stress and cell membrane scrambling.

Mitoxantrone further increased the abundance of ceramide, another powerful stimulator of eryptosis [28]. Mitoxantrone may stimulate ceramide formation by activation of sphingomyelinase in nucleated cells [92]. Mitoxantrone has been shown to stimulate phospholipase C with subsequent hydrolysis of phosphatidylcholine [92]. In erythrocytes, sphingomyelinase and thus ceramide formation are stimulated by platelet activating factor [93, 94]. Ceramide has been shown to trigger cell membrane scrambling in part by sensibilisation against $\mathrm{Ca}^{2+}$ [93]. The present observations rather suggest $\mathrm{Ca}^{2+}$ independence of mitoxantroneinduced eryptosis.

Eryptosis is a physiological mechanism accomplishing removal of defective erythrocytes from circulating blood. Phosphatidylserine exposing erythrocytes bind to respective receptors of phagocyting cells which engulf and degrade the defective erythrocytes [28]. Accordingly, phosphatidylserine exposing erythrocytes are rapidly cleared from circulating blood [28]. Stimulation of eryptotic cell shrinkage [29] counteracts erythrocyte swelling, which could, at least in theory, result in hemolysis with subsequent rupture of the cell membrane and release of cellular hemoglobin. Hemoglobin released from hemolytic erythrocytes may be filtered in renal glomeruli, undergo subsequent precipitation in renal tubules, occlude tubular lumina and thus lead to obstructive kidney injury [95].

Excessive eryptosis may be similarly harmful. Removal of phosphatidylserine exposing erythrocytes from circulating blood may result in anemia, as soon as the loss of eryptotic erythrocytes exceeds the parallel formation of new erythrocytes [28]. Phosphatidylserine exposing erythrocytes furher adhere to the vascular wall by binding of erythrocytic phosphatidylserine to endothelial CXCL16 [96]. The binding of eryptotic erythrocytes to the vascular wall impedes microcirculation [96-101]. Phosphatidylserine exposing erythrocytes may further foster blood clotting and thus thrombosis [97, 102, 103].

In conclusion, mitoxantrone triggers eryptosis with erythrocyte shrinkage and cell membrane scrambling. Cellular mechanisms involved in the pro-eryptotic effect of mitoxantrone include oxidative stress and ceramide formation.

\section{Acknowledgements}

The authors acknowledge the meticulous preparation of the manuscript by Tanja Loch. The study was supported by the Deutsche Forschungsgemeinschaft and the Open Access Publishing Fund of Tuebingen University.

\section{References}

1 Martinelli V, Radaelli M, Straffi L, Rodegher M, Comi G: Mitoxantrone: benefits and risks in multiple sclerosis patients. Neurol Sci 2009;30:S167-170. 
2 Martinelli Boneschi F, Vacchi L, Rovaris M, Capra R, Comi G: Mitoxantrone for multiple sclerosis. Cochrane Database Syst Rev 2013;5:CD002127.

-3 Gyan E, Damotte D, Courby S, Senecal D, Quittet P, Schmidt-Tanguy A, Banos A, Le Gouill S, Lamy T, Fontan J, Maisonneuve H, Alexis M, Dreyfus F, Tournilhac O, Laribi K, Solal-Celigny P, Arakelyan N, Cartron G, Gressin R, Group G: High response rate and acceptable toxicity of a combination of rituximab, vinorelbine, ifosfamide, mitoxantrone and prednisone for the treatment of diffuse large B-cell lymphoma in first relapse: results of the R-NIMP GOELAMS study. Br J Haematol 2013;162:240-249.

4 He X, Wang J, Dou J, Yu F, Cai K, Li X, Zhang H, Gu N: Antitumor efficacy induced by a B16F10 tumor cell vaccine treated with mitoxantrone alone or in combination with reserpine and verapamil in mice. Exp Ther Med 2011;2:911-916.

5 Lee KJ, An JH, Chun JR, Chung KH, Park WY, Shin JS, Kim DH, Bahk YY: In vitro analysis of the anti-cancer activity of mitoxantrone loaded on magnetic nanoparticles. J Biomed Nanotechnol 2013;9:1071-1075.

6 Miranda E, Maya Pineda H, Oberg D, Cherubini G, Garate Z, Lemoine NR, Hallden G: Adenovirus-mediated sensitization to the cytotoxic drugs docetaxel and mitoxantrone is dependent on regulatory domains in the E1ACR1 gene-region. PLoS One 2012; 7:e46617.

7 Yagublu V, Caliskan N, Lewis AL, Jesenofsky R, Gasimova L, Lohr JM, Keese M: Treatment of experimental pancreatic cancer by doxorubicin-, mitoxantrone-, and irinotecan-drug eluting beads. Pancreatology 2013;13:79-87.

8 Zhao H, Rybak P, Dobrucki J, Traganos F, Darzynkiewicz Z: Relationship of DNA damage signaling to DNA replication following treatment with DNA topoisomerase inhibitors camptothecin/topotecan, mitoxantrone, or etoposide. Cytometry A 2012;81:45-51.

-9 Keese M, Gasimova L, Schwenke K, Yagublu V, Shang E, Faissner R, Lewis A, Samel S, Lohr M: Doxorubicin and mitoxantrone drug eluting beads for the treatment of experimental peritoneal carcinomatosis in colorectal cancer. Int J Cancer 2009;124:2701-2708.

$>10$ Mimeault M, Mehta PP, Hauke R, Henichart JP, Depreux P, Lin MF, Batra SK: Improvement of cytotoxic effects induced by mitoxantrone on hormone-refractory metastatic prostate cancer cells by co-targeting epidermal growth factor receptor and hedgehog signaling cascades. Growth Factors 2007;25:400-416.

11 Cao C, Han Y, Ren Y, Wang Y: Mitoxantrone-mediated apoptotic B16-F1 cells induce specific anti-tumor immune response. Cell Mol Immunol 2009;6:469-475.

12 Dubielecka PM, Grzybek M, Kolondra A, Jazwiec B, Draga A, Aleksandrowicz P, Kolodziejczyk M, Serwotka A, Dolinska-Krajewska B, Warchol J, Kuliczkowski K, Sikorski AF: Aggregation of spectrin and PKCtheta is an early hallmark of fludarabine/mitoxantrone/dexamethasone-induced apoptosis in Jurkat T and HL60 cells. Mol Cell Biochem 2010;339:63-77.

13 Grandhi TS, Potta T, Taylor DJ, Tian Y, Johnson RH, Meldrum DR, Rege K: Sensitizing cancer cells to TRAILinduced death by micellar delivery of mitoxantrone. Nanomedicine (Lond) 2013;10.2217/nnm.13.125

14 Kostrzewa-Nowak D, Tarasiuk J: Bioreductive activation of mitoxantrone by NADPH cytochrome P450 reductase does not change its apoptotic stimuli properties in regard to sensitive and multidrug resistant leukaemia HL60 cells. Eur J Pharmacol 2013;721:141-150.

15 Li JM, Yang Y, Zhu P, Zheng F, Gong FL, Mei YW: Mitoxantrone exerts both cytotoxic and immunoregulatory effects on activated microglial cells. Immunopharmacol Immunotoxicol 2012;34:36-41.

16 Li Y, Zhao L, Sun H, Yu J, Li N, Liang J, Wang Y, He M, Bai X, Yu Z, Zheng Z, Mi X, Wang E, Wei M: Gene silencing of FANCF potentiates the sensitivity to mitoxantrone through activation of JNK and p38 signal pathways in breast cancer cells. PLoS One 2012;7:e44254.

$>17$ Symes JC, Kurin M, Fleshner NE, Medin JA: Fas-mediated killing of primary prostate cancer cells is increased by mitoxantrone and docetaxel. Mol Cancer Ther 2008;7:3018-3028.

18 Neuhaus O, Wiendl H, Kieseier BC, Archelos JJ, Hemmer B, Stuve O, Hartung HP: Multiple sclerosis: Mitoxantrone promotes differential effects on immunocompetent cells in vitro. J Neuroimmunol 2005;168:128-137.

19 Seifrtova M, Havelek R, Soukup T, Filipova A, Mokry J, Rezacova M: Mitoxantrone ability to induce premature senescence in human dental pulp stem cells and human dermal fibroblasts. J Physiol Pharmacol 2013;64:255-266.

20 Chan A, Lo-Coco F: Mitoxantrone-related acute leukemia in MS: an open or closed book? Neurology 2013;80:1529-1533. 
21 Kingwell E, Koch M, Leung B, Isserow S, Geddes J, Rieckmann P, Tremlett H: Cardiotoxicity and other adverse events associated with mitoxantrone treatment for MS. Neurology 2010;74:1822-1826.

22 DiPaola RS, Chen YH, Stein M, Vaughn D, Patrick-Miller L, Carducci M, Roth B, White E, Wilding G: A randomized phase II trial of mitoxantrone, estramustine and vinorelbine or bcl-2 modulation with 13-cis retinoic acid, interferon and paclitaxel in patients with metastatic castrate-resistant prostate cancer: ECOG 3899. J Transl Med 2010;8:20.

-23 Font A, Murias A, Arroyo FR, Martin C, Areal J, Sanchez JJ, Santiago JA, Constenla M, Saladie JM, Rosell R: Sequential mitoxantrone/prednisone followed by docetaxel/estramustine in patients with hormone refractory metastatic prostate cancer: results of a phase II study. Ann Oncol 2005;16:419-424.

24 Galli L, Fontana A, Galli C, Landi L, Fontana E, Antonuzzo A, Andreuccetti M, Aitini E, Barbieri R, Di Marsico R, Falcone A: Phase II study of sequential chemotherapy with docetaxel-estramustine followed by mitoxantrone-prednisone in patients with advanced hormone-refractory prostate cancer. Br J Cancer 2007;97:1613-1617.

25 Greidanus J, de Vries EG, Mulder NH, Sleijfer DT, Uges DR, Oosterhuis B, Willemse PH: A phase I pharmacokinetic study of 21-day continuous infusion mitoxantrone. J Clin Oncol 1989;7:790-797.

-26 Ho AD, Del Valle F, Engelhard M, Hiddemann W, Ruckle H, Schlimok G, Haas R, Thiel E, Andreesen R, Fiedler W, et al.: Mitoxantrone/high-dose Ara-C and recombinant human GM-CSF in the treatment of refractory non-Hodgkin's lymphoma. A pilot study. Cancer 1990;66:423-430.

27 Shepherd FA, Evans WK, Blackstein ME, Fine S, Heathcote J, Langer B, Taylor B, Habal F, Kutas G, Pritchard $\mathrm{KI}$, et al.: Hepatic arterial infusion of mitoxantrone in the treatment of primary hepatocellular carcinoma. J Clin Oncol 1987;5:635-640.

-28 Lang E, Qadri SM, Lang F: Killing me softly - suicidal erythrocyte death. Int J Biochem Cell Biol 2012;44:1236-1243.

-29 Lang PA, Kaiser S, Myssina S, Wieder T, Lang F, Huber SM: Role of Ca2+-activated K+ channels in human erythrocyte apoptosis. Am J Physiol Cell Physiol 2003;285:C1553-C1560.

-30 Bhavsar SK, Bobbala D, Xuan NT, Foller M, Lang F: Stimulation of suicidal erythrocyte death by alpha-lipoic acid. Cell Physiol Biochem. 2010;26:859-868.

31 Foller M, Huber SM, Lang F: Erythrocyte programmed cell death. IUBMB Life 2008;60:661-668.

-32 Foller M, Mahmud H, Gu S, Wang K, Floride E, Kucherenko Y, Luik S, Laufer S, Lang F: Participation of leukotriene C(4) in the regulation of suicidal erythrocyte death. J Physiol Pharmacol 2009;60:135-143.

33 Lau IP, Chen H, Wang J, Ong HC, Leung KC, Ho HP, Kong SK: In vitro effect of CTAB- and PEG-coated gold nanorods on the induction of eryptosis/erythroptosis in human erythrocytes. Nanotoxicology 2012;6:847856.

34 Maellaro E, Leoncini S, Moretti D, Del Bello B, Tanganelli I, De Felice C, Ciccoli L: Erythrocyte caspase-3 activation and oxidative imbalance in erythrocytes and in plasma of type 2 diabetic patients. Acta Diabetol 2013;50:489-495.

-35 Foller M, Sopjani M, Koka S, Gu S, Mahmud H, Wang K, Floride E, Schleicher E, Schulz E, Munzel T, Lang F: Regulation of erythrocyte survival by AMP-activated protein kinase. FASEB J 2009;23:1072-1080.

-36 Foller M, Feil S, Ghoreschi K, Koka S, Gerling A, Thunemann M, Hofmann F, Schuler B, Vogel J, Pichler B, Kasinathan RS, Nicolay JP, Huber SM, Lang F, Feil R: Anemia and splenomegaly in cGKI-deficient mice. Proc Natl Acad Sci USA 2008;105:6771-6776.

-37 Zelenak C, Foller M, Velic A, Krug K, Qadri SM, Viollet B, Lang F, Macek B: Proteome analysis of erythrocytes lacking AMP-activated protein kinase reveals a role of PAK2 kinase in eryptosis. J Proteome Res 2011;10:1690-1697.

38 Lupescu A, Shaik N, Jilani K, Zelenak C, Lang E, Pasham V, Zbidah M, Plate A, Bitzer M, Foller M, Qadri SM, Lang F: Enhanced Erythrocyte Membrane Exposure of Phosphatidylserine Following Sorafenib Treatment: An in vivo and in vitro Study. Cell Physiol Biochem 2012;30:876-888.

39 Shaik N, Lupescu A, Lang F: Sunitinib-sensitive suicidal erythrocyte death. Cell Physiol Biochem 2012;30:512-522.

40 Kucherenko Y, Zelenak C, Eberhard M, Qadri SM, Lang F: Effect of casein kinase 1alpha activator pyrvinium pamoate on erythrocyte ion channels. Cell Physiol Biochem 2012;30:407-417.

41 Zelenak C, Eberhard M, Jilani K, Qadri SM, Macek B, Lang F: Protein kinase CK1alpha regulates erythrocyte survival. Cell Physiol Biochem 2012;29:171-180. 
42 Bhavsar SK, Gu S, Bobbala D, Lang F: Janus kinase 3 is expressed in erythrocytes, phosphorylated upon energy depletion and involved in the regulation of suicidal erythrocyte death. Cell Physiol Biochem 2011;27:547-556.

43 Klarl BA, Lang PA, Kempe DS, Niemoeller OM, Akel A, Sobiesiak M, Eisele K, Podolski M, Huber SM, Wieder T, Lang F: Protein kinase C mediates erythrocyte "programmed cell death" following glucose depletion. Am J Physiol Cell Physiol 2006;290:C244-C253.

44 Gatidis S, Zelenak C, Fajol A, Lang E, Jilani K, Michael D, Qadri SM, Lang F: p38 MAPK activation and function following osmotic shock of erythrocytes. Cell Physiol Biochem 2011;28:1279-1286.

45 Sinha A, Singh A, Satchidanandam V, Natarajan K: Impaired generation of reactive oxygen species during differentiation of dendritic cells (DCs) by Mycobacterium tuberculosis secretory antigen (MTSA) and subsequent activation of MTSA-DCs by mycobacteria results in increased intracellular survival. J Immunol 2006;177:468-478.

46 Canal P, Attal M, Chatelut E, Guichard S, Huguet F, Muller C, Schlaifer D, Laurent G, Houin G, Bugat R: Plasma and cellular pharmacokinetics of mitoxantrone in high-dose chemotherapeutic regimen for refractory lymphomas. Cancer Res 1993;53:4850-4854.

47 Abed M, Towhid ST, Mia S, Pakladok T, Alesutan I, Borst O, Gawaz M, Gulbins E, Lang F: Sphingomyelinaseinduced adhesion of eryptotic erythrocytes to endothelial cells. Am J Physiol Cell Physiol 2012;303:C991999.

48 Bottger E, Multhoff G, Kun JF, Esen M: Plasmodium falciparum-infected erythrocytes induce granzyme B by NK cells through expression of host-Hsp70. PLoS One 2012;7:e33774.

49 Firat U, Kaya S, Cim A, Buyukbayram H, Gokalp O, Dal MS, Tamer MN: Increased caspase-3 immunoreactivity of erythrocytes in STZ diabetic rats. Exp Diabetes Res 2012;2012:316384.

50 Ganesan S, Chaurasiya ND, Sahu R, Walker LA, Tekwani BL: Understanding the mechanisms for metabolism-linked hemolytic toxicity of primaquine against glucose 6-phosphate dehydrogenase deficient human erythrocytes: evaluation of eryptotic pathway. Toxicology 2012;294:54-60.

51 Gao M, Cheung KL, Lau IP, Yu WS, Fung KP, Yu B, Loo JF, Kong SK: Polyphyllin D induces apoptosis in human erythrocytes through $\mathrm{Ca}(2)(+)$ rise and membrane permeabilization. Arch Toxicol 2012;86:741-752.

52 Ghashghaeinia M, Cluitmans JC, Akel A, Dreischer P, Toulany M, Koberle M, Skabytska Y, Saki M, Biedermann T, Duszenko M, Lang F, Wieder T, Bosman GJ: The impact of erythrocyte age on eryptosis. Br J Haematol 2012;157:606-614.

53 Jilani K, Lupescu A, Zbidah M, Abed M, Shaik N, Lang F: Enhanced Apoptotic Death of Erythrocytes Induced by the Mycotoxin Ochratoxin A. Kidney Blood Press Res 2012;36:107-118.

54 Jilani K, Lupescu A, Zbidah M, Shaik N, Lang F: Withaferin A-stimulated Ca2+ entry, ceramide formation and suicidal death of erythrocytes. Toxicol In Vitro 2013;27:52-58.

55 Kucherenko YV, Lang F: Inhibitory Effect of Furosemide on Non-Selective Voltage-Independent Cation Channels in Human Erythrocytes. Cell Physiol Biochem 2012;30:863-875.

56 Lang E, Jilani K, Zelenak C, Pasham V, Bobbala D, Qadri SM, Lang F: Stimulation of suicidal erythrocyte death by benzethonium. Cell Physiol Biochem 2011;28:347-354.

57 Lang E, Qadri SM, Jilani K, Zelenak C, Lupescu A, Schleicher E, Lang F: Carbon monoxide-sensitive apoptotic death of erythrocytes. Basic Clin Pharmacol Toxicol 2012;111:348-355.

58 Lupescu A, Jilani K, Zbidah M, Lang E, Lang F: Enhanced Ca(2+) Entry, Ceramide Formation, and Apoptotic Death of Erythrocytes Triggered by Plumbagin. J Nat Prod 2012;10.1021/np300611r

59 Lupescu A, Jilani K, Zbidah M, Lang F: Induction of apoptotic erythrocyte death by rotenone. Toxicology 2012;300:132-137.

60 Polak-Jonkisz D, Purzyc L: Ca Influx versus Efflux during Eryptosis in Uremic Erythrocytes. Blood Purif 2012;34:209-210.

61 Qian EW, Ge DT, Kong SK: Salidroside protects human erythrocytes against hydrogen peroxide-induced apoptosis. J Nat Prod 2012;75:531-537.

62 Shaik N, Zbidah M, Lang F: Inhibition of $\mathrm{Ca}(2+)$ entry and suicidal erythrocyte death by naringin. Cell Physiol Biochem 2012;30:678-686.

-63 Vota DM, Maltaneri RE, Wenker SD, Nesse AB, Vittori DC: Differential erythropoietin action upon cells induced to eryptosis by different agents. Cell Biochem Biophys 2013;65:145-157. 
64 Weiss E, Cytlak UM, Rees DC, Osei A, Gibson JS: Deoxygenation-induced and Ca(2+) dependent phosphatidylserine externalisation in red blood cells from normal individuals and sickle cell patients. Cell Calcium 2012;51:51-56.

65 Zappulla D: Environmental stress, erythrocyte dysfunctions, inflammation, and the metabolic syndrome: adaptations to CO2 increases? J Cardiometab Syndr 2008;3:30-34.

66 Zbidah M, Lupescu A, Jilani K, Lang F: Stimulation of suicidal erythrocyte death by fumagillin. Basic Clin Pharmacol Toxicol 2013;112:346-351.

67 Zbidah M, Lupescu A, Shaik N, Lang F: Gossypol-induced suicidal erythrocyte death. Toxicology 2012;302:101-105.

68 Zelenak C, Pasham V, Jilani K, Tripodi PM, Rosaclerio L, Pathare G, Lupescu A, Faggio C, Qadri SM, Lang F: Tanshinone IIA stimulates erythrocyte phosphatidylserine exposure. Cell Physiol Biochem 2012;30:282294.

69 Abed M, Herrmann T, Alzoubi K, Pakladok T, Lang F: Tannic Acid induced suicidal erythrocyte death. Cell Physiol Biochem 2013;32:1106-1116.

70 Ahmed MS, Langer H, Abed M, Voelkl J, Lang F: The uremic toxin acrolein promotes suicidal erythrocyte death. Kidney Blood Press Res 2013;37:158-167.

71 Ghashghaeinia M, Cluitmans JC, Toulany M, Saki M, Koberle M, Lang E, Dreischer P, Biedermann T, Duszenko M, Lang F, Bosman GJ, Wieder T: Age Sensitivity of NFkappaB Abundance and Programmed Cell Death in Erythrocytes Induced by NFkappaB Inhibitors. Cell Physiol Biochem 2013;32:801-813.

72 Lupescu A, Jilani K, Zbidah M, Lang F: Patulin-induced suicidal erythrocyte death. Cell Physiol Biochem 2013;32:291-299.

73 Voelkl J, Alzoubi K, Mamar AK, Ahmed MS, Abed M, Lang F: Stimulation of suicidal erythrocyte death by increased extracellular phosphate concentrations. Kidney Blood Press Res 2013;38:42-51.

74 Calderon-Salinas JV, Munoz-Reyes EG, Guerrero-Romero JF, Rodriguez-Moran M, Bracho-Riquelme RL, Carrera-Gracia MA, Quintanar-Escorza MA: Eryptosis and oxidative damage in type 2 diabetic mellitus patients with chronic kidney disease. Mol Cell Biochem 2011;357:171-179.

75 Nicolay JP, Schneider J, Niemoeller OM, Artunc F, Portero-Otin M, Haik G Jr, Thornalley PJ, Schleicher E, Wieder T, Lang F: Stimulation of suicidal erythrocyte death by methylglyoxal. Cell Physiol Biochem 2006;18:223-232.

76 Abed M, Feger M, Alzoubi K, Pakladok T, Frauenfeld L, Geiger C, Towhid ST, Lang F: Sensitization of erythrocytes to suicidal erythrocyte death following water deprivation. Kidney Blood Press Res 2013;37:567-578.

77 Myssina S, Huber SM, Birka C, Lang PA, Lang KS, Friedrich B, Risler T, Wieder T, Lang F: Inhibition of erythrocyte cation channels by erythropoietin. J Am Soc Nephrol 2003;14:2750-2757.

78 Abed M, Artunc F, Alzoubi K, Honisch S, Baumann D, Foller M, Lang F: Suicidal erythrocyte death in endstage renal disease. J Mol Med (Berl) 2014;10.1007/s00109-014-1151-4

79 Lang PA, Beringer O, Nicolay JP, Amon O, Kempe DS, Hermle T, Attanasio P, Akel A, Schafer R, Friedrich B, Risler T, Baur M, Olbricht CJ, Zimmerhackl LB, Zipfel PF, Wieder T, Lang F: Suicidal death of erythrocytes in recurrent hemolytic uremic syndrome. J Mol Med (Berl) 2006;84:378-388.

-80 Kempe DS, Akel A, Lang PA, Hermle T, Biswas R, Muresanu J, Friedrich B, Dreischer P, Wolz C, Schumacher U, Peschel A, Gotz F, Doring G, Wieder T, Gulbins E, Lang F: Suicidal erythrocyte death in sepsis. J Mol Med 2007;85:269-277.

-81 Foller M, Bobbala D, Koka S, Huber SM, Gulbins E, Lang F: Suicide for survival--death of infected erythrocytes as a host mechanism to survive malaria. Cell Physiol Biochem. 2009;24:133-140.

82 Lang PA, Schenck M, Nicolay JP, Becker JU, Kempe DS, Lupescu A, Koka S, Eisele K, Klarl BA, Rubben H, Schmid KW, Mann K, Hildenbrand S, Hefter H, Huber SM, Wieder T, Erhardt A, Haussinger D, Gulbins E, Lang F: Liver cell death and anemia in Wilson disease involve acid sphingomyelinase and ceramide. Nat Med 2007;13:164-170.

-83 Kempe DS, Lang PA, Duranton C, Akel A, Lang KS, Huber SM, Wieder T, Lang F: Enhanced programmed cell death of iron-deficient erythrocytes. FASEB J 2006;20:368-370.

-84 Qadri SM, Mahmud H, Lang E, Gu S, Bobbala D, Zelenak C, Jilani K, Siegfried A, Foller M, Lang F: Enhanced suicidal erythrocyte death in mice carrying a loss-of-function mutation of the adenomatous polyposis coli gene. J Cell Mol Med 2012;16:1085-1093. 
85 Birka C, Lang PA, Kempe DS, Hoefling L, Tanneur V, Duranton C, Nammi S, Henke G, Myssina S, Krikov M, Huber SM, Wieder T, Lang F: Enhanced susceptibility to erythrocyte "apoptosis" following phosphate depletion. Pflugers Arch 2004;448:471-477.

86 Albertsson P, Lennernas B, Norrby K: Low-dosage metronomic chemotherapy and angiogenesis: topoisomerase inhibitors irinotecan and mitoxantrone stimulate VEGF-A-mediated angiogenesis. APMIS 2012;120:147-156.

87 Rossato LG, Costa VM, Vilas-Boas V, de Lourdes Bastos M, Rolo A, Palmeira C, Remiao F: Therapeutic concentrations of mitoxantrone elicit energetic imbalance in h9c2 cells as an earlier event. Cardiovasc Toxicol 2013;13:413-425.

-88 Vibet S, Maheo K, Gore J, Dubois P, Bougnoux P, Chourpa I: Differential subcellular distribution of mitoxantrone in relation to chemosensitization in two human breast cancer cell lines. Drug Metab Dispos 2007;35:822-828.

89 Adamczyk-Sowa M, Sowa P, Pierzchala K, Polaniak R, Labuz-Roszak B: Antioxidative enzymes activity and malondialdehyde concentration during mitoxantrone therapy in multiple sclerosis patients. J Physiol Pharmacol 2012;63:683-690.

90 Jamroz-Wisniewska A, Beltowski J, Stelmasiak Z, Bartosik-Psujek H: Paraoxonase 1 activity in multiple sclerosis patients during mitoxantrone therapy. Acta Neurol Scand 2013;127:e33-36.

-91 Lang F, Abed M, Lang E, Foller M: Oxidative stress and suicidal erythrocyte death. Antioxid Redox Signal 2014;21:138-153.

92 Bettaieb A, Plo I, Mansat-De Mas V, Quillet-Mary A, Levade T, Laurent G, Jaffrezou JP: Daunorubicin- and mitoxantrone-triggered phosphatidylcholine hydrolysis: implication in drug-induced ceramide generation and apoptosis. Mol Pharmacol 1999;55:118-125.

-93 Lang F, Gulbins E, Lang PA, Zappulla D, Foller M: Ceramide in suicidal death of erythrocytes. Cell Physiol Biochem 2010;26:21-28.

\$94 Lang PA, Kempe DS, Tanneur V, Eisele K, Klarl BA, Myssina S, Jendrossek V, Ishii S, Shimizu T, Waidmann M, Hessler G, Huber SM, Lang F, Wieder T: Stimulation of erythrocyte ceramide formation by plateletactivating factor. J Cell Sci 2005;118:1233-1243.

-95 Harrison HE, Bunting H, Ordway NK, Albrink WS: The Pathogenesis of the Renal Injury Produced in the Dog by Hemoglobin or Methemoglobin. J Exp Med 1947;86:339-356.

-96 Borst O, Abed M, Alesutan I, Towhid ST, Qadri SM, Foller M, Gawaz M, Lang F: Dynamic adhesion of eryptotic erythrocytes to endothelial cells via CXCL16/SR-PSOX. Am J Physiol Cell Physiol 2012;302:C644-C651.

-97 Andrews DA, Low PS: Role of red blood cells in thrombosis. Curr.Opin.Hematol. 1999;6:76-82.

98 Closse C, Dachary-Prigent J, Boisseau MR: Phosphatidylserine-related adhesion of human erythrocytes to vascular endothelium. Br J Haematol 1999;107:300-302.

99 Gallagher PG, Chang SH, Rettig MP, Neely JE, Hillery CA, Smith BD, Low PS: Altered erythrocyte endothelial adherence and membrane phospholipid asymmetry in hereditary hydrocytosis. Blood 2003;101:46254627.

100 Pandolfi A, Di Pietro N, Sirolli V, Giardinelli A, Di Silvestre S, Amoroso L, Di Tomo P, Capani F, Consoli A, Bonomini M: Mechanisms of uremic erythrocyte-induced adhesion of human monocytes to cultured endothelial cells. J Cell Physiol 2007;213:699-709.

101 Wood BL, Gibson DF, Tait JF: Increased erythrocyte phosphatidylserine exposure in sickle cell disease: flowcytometric measurement and clinical associations. Blood 1996;88:1873-1880.

102 Chung SM, Bae ON, Lim KM, Noh JY, Lee MY, Jung YS, Chung JH: Lysophosphatidic acid induces thrombogenic activity through phosphatidylserine exposure and procoagulant microvesicle generation in human erythrocytes. Arterioscler Thromb Vasc Biol 2007;27:414-421.

103 Zwaal RF, Comfurius P, Bevers EM: Surface exposure of phosphatidylserine in pathological cells. Cell Mol Life Sci 2005;62:971-988. 